\title{
THE SHORT-TERM RELATION AMONG STOCK INVESTORS IN BORSA ISTANBUL: EFFECT OF COVID-19
}

\author{
DOI: 10.17261/Pressacademia.2021.1433 \\ PAP- V.13-2021(22)-p.101
}

Cumhur Ekinci ${ }^{1}$, Oguz Ersan ${ }^{2}$

${ }^{1}$ Istanbul Technical University, Faculty of Management, Istanbul, Turkey. ekincicu@itu.edu.tr, ORCID: 0000-0002-0475-2272

${ }^{2}$ Kadir Has University, School of Economics and Adminstartive Sciences, Istanbul, Turkey. oguzersan@khas.edu.tr, ORCID: 0000-0003-3135-5317

To cite this document

Ekinci, C., Ersan, O. (2021). The short-term relation among stock investors in Borsa Istanbul: effect of Covid-19. PressAcademia Procedia (PAP), V.13, 101.

Permanent link to this document: http://doi.org/10.17261/Pressacademia.2021.1433

Copyright: Published by PressAcademia and limited licensed re-use rights only.

\section{ABSTRACT}

Purpose- The purpose of this study is to determine the short-term impact of various types of investors on each other. Secondly, it tries to understand whether COVID-19 had a significant change in the relationship between these investors.

Methodology- Based on the transactions data, the study classifies investor groups such as fast and slow traders, domestic and foreign investors, bank-based and non-bank based brokers. Then, it employs a panel vector autoregression model in order to find any reciprocal relation.

Findings- The analysis reveals that, with the start of the pandemic, the impact of intraday returns on investors and the response of slow foreign investors to market returns did not change very much. On the other hand, the response of other investors such as retail/professional or fast/slow domestic investors as well as fast foreign investors significantly altered.

Conclusion- Based upon the empirical analysis, it may be concluded that different types of investors have positive or negative impact on each other and investor behavior has been seriously affected by COVID-19.

Keywords: Fast traders, foreign investors, brokers, Borsa Istanbul, panel vector autoregression JEL Codes: G10, G14, G21

\section{REFERENCES}

Arellano, M., and Bover, O. (1995). Another look at the instrumental variable estimation of error-components models. Journal of Econometrics, 68(1), 29-51.

Barber, B.M., and Odean, T. (2008). All that glitters: The effect of attention and news on the buying behavior of individual and institutional investors. Review of Financial Studies, 21(2), 785-818.

Bekiros, S., Jlassi, M., Lucey, B., Naoui, K., and Uddin, G.S. (2017). Herding behavior, market sentiment and volatility: Will the bubble resume? North American Journal of Economics and Finance, 42, 107-131.

Choe, H., Kho, B.C., and Stulz, R.M. (1999). Do foreign investors destabilize stock markets? The Korean experience in 1997. Journal of Financial Economics, 54(2), 227-264.

Coval, J.D. and Moskowitz, T.J. (1999). Home bias at home: Local equity preference in domestic portfolios. Journal of Finance, 54(6), 20452073.

Dvorak, T. (2005). Do domestic investors have an information advantage? Evidence from Indonesia. Journal of Finance, 60(2), 817-839.

Griffin, J.M., Harris, J.H., and Topaloglu, S. (2003). The dynamics of institutional and individual trading. Journal of Finance, 58(6), 2285-2320.

Grinblatt, M. and Keloharju, M. (2000). The investment behavior and performance of various investor types: a study of Finland's unique data set. Journal of Financial Economics, 55(1), 43-67.

Hasbrouck, J. (2018). High-Frequency Quoting: Short-Term Volatility in Bids and Offers. Journal of Financial and Quantitative Analysis, 53(2), 613-641.

Kirilenko, A., Kyle, A.S., Samadi, M., and Tuzun, T. (2017). The flash crash: High-frequency trading in an electronic market. Journal of Finance, 72(3), 967-998

Kumar, A. and Lee, C.M. (2006). Retail investor sentiment and return comovements. Journal of Finance, 61(5), 2451-2486. 